\title{
Herbicide Effects on Sugarcane Growth, Pythium Root Rot, and Pythium arrhenomanes
}

\author{
N. Dissanayake, J. W. Hoy, and J. L. Griffin
}

Department of Plant Pathology and Crop Physiology, Louisiana State University Agricultural Center, Baton Rouge 70803. Accepted for publication 3 March 1998.

\begin{abstract}
Dissanayake, N., Hoy, J. W., and Griffin, J. L. 1998. Herbicide effects on sugarcane growth, Pythium root rot, and Pythium arrhenomanes. Phytopathology 88:530-535.

Six herbicides were evaluated for their effects on Pythium root rot and growth of sugarcane in greenhouse experiments and on in vitro mycelial growth rate of Pythium arrhenomanes. Pendimethalin and atrazine were most inhibitory to mycelial growth, but neither reduced root rot severity. Asulam, atrazine, and metribuzin were not phytotoxic to sugarcane and did

not affect root rot symptom severity in clay loam or silt loam field soils. Atrazine and metribuzin increased shoot number, and atrazine increased total shoot weight for treated plants in silt loam soil. Glyphosate, pendimethalin, and terbacil were phytotoxic to sugarcane. These herbicides increased root rot severity, but the extent to which growth reductions resulted from increased disease severity or from direct herbicide injury was not clear. Adverse effects on plant growth and root rot severity were greater in clay loam than in silt loam soil. The results suggest that sugarcane injury from some herbicides is compounded by increased severity of root rot.
\end{abstract}

Sugarcane production in Louisiana is adversely affected by a complex yield decline now known as stubble decline $(14,16,23$, 24). Sugarcane is clonally propagated by planting stalks, and successive annual cuttings are obtained from a single planting. Ratoon or stubble crops develop from buds on the basal portions of plants remaining after harvest. Stubble decline is characterized by progressive reductions in stubble germination and growth, resulting in yield reductions in the successive ratoon crops. This limits the crop cycle to 3 years, the plant cane crop and two ratoon crops. The producer must then fallow the field the fourth year and replant during late summer to early fall. Replanting is expensive, not only because of time, labor, and equipment investment, but also because revenue is lost in the use of cane for planting. Consequently, if the grower can increase the number of years in the crop cycle, the return on investment is greater.

Many environmental, cultural, and biological factors are associated with stubble decline. Among these are Pythium root rot, caused by Pythium arrhenomanes Drechs. $(15,23,24,34)$, and stress from weed competition. Weeds can compete with the crop for space, nutrients, and water and can serve as alternative hosts for pathogens. Weed control, accomplished primarily by tillage and use of herbicides, is critical to maximizing yield of sugarcane in Louisiana.

In addition to the primary role of reducing weed competition, herbicides can have other indirect and direct effects on the growth of crop plants. Herbicides may affect plant-pathogenic soilborne fungi and the occurrence or severity of root diseases $(2-4,20,27$, 31,40). Plant diseases may be enhanced by indirect herbicide effects on soil microorganisms that normally are antagonistic to root pathogens $(5,6)$. Some herbicides may cause direct injury to crop plants, adversely affecting disease-resistance mechanisms and predisposing them to root diseases $(7,25,29,30)$. Sublethal injury to plants can result in altered membrane permeability in root tissues and subsequent leakage of cellular contents into the root-soil interface $(21,22)$. Evidence suggests that propagules of some Pythium spp. depend on exogenous nutrients for germination and ultimately for successful host infection $(17,26)$.

Corresponding author: J.W. Hoy; E-mail address: jhoy@unix1.sncc. 1su.edu

Publication no. P-1998-0406-01R

(C) 1998 The American Phytopathological Society
There are additional possible effects of herbicides on the interactions between hosts and soilborne pathogens. Chemicals applied to the foliage can be translocated downward in plants and released from roots into the soil, either intact or as metabolic by-products (22). Some chemicals with fungicidal properties have been shown to provide disease suppression in field studies $(18,19,37,41)$. Another mechanism of reducing disease severity appears to be reduction in germination rates of pathogen propagules caused by enhanced soil fungistasis (8).

Some herbicides have growth-regulating properties that stimulate plant growth (44). Conversely, plants affected with sublethal levels of root rot may be more vulnerable to damage by herbicide treatments (2). Therefore, in addition to determining the conditions and practices under which maximum herbicide efficacy is obtained with regard to weed control, it also is important to elucidate the herbicide-host-disease interactions that can affect crop growth and yield.

No information is available on the nontarget effects of herbicides on $P$. arrhenomanes and Pythium root rot of sugarcane. The purpose of this investigation was to determine whether six herbicides commonly used for weed control and one also used as a ripening agent affect $P$. arrhenomanes, Pythium root rot, and sugarcane growth. Preliminary results of this research have been reported (12).

\section{MATERIALS AND METHODS}

Evaluation of herbicide effects on Pythium root rot and growth of sugarcane. Experiments were conducted during the spring of 1993, the winter of 1993 to 1994, and the winter of 1994 to 1995 in the greenhouse. Two soils were used in each experiment: a Commerce silt loam from the St. Gabriel Research Station of the Louisiana Agricultural Experiment Station in Iberville Parish and a Commerce clay loam from a sugarcane farm in West Baton Rouge Parish.

Soil of each type was sieved through a 1-cm-mesh screen and mixed with sterile sand to a final field soil-sand ratio of 2:1 (vol/vol). A portion of the soil mixture was left unchanged and will be referred to as field soil (FS). Another portion was steam sterilized (steam treated for $24 \mathrm{~h}$ in $50-\times 70-\times 8-\mathrm{cm}$ metal trays) and will be referred to as steam-treated field soil (SFS). A third portion of the silt loam soil-sand mixture was steam treated and then infested with $P$. arrhenomanes inoculum and will be referred to as $P$. arrhen- 
omanes-infested SFS (SFS+Pa). The Pythium inoculum was prepared and added to soil as described previously (23).

Three-week-old sugarcane plants of cultivar CP 70-321 with three to five leaves grown from single-bud cuttings were transplanted (one plant per $15-\mathrm{cm}$-diameter clay pot). Herbicides were applied 1 day after transplanting at rates recommended on the label for each as follows: atrazine (Atrazine 4L; Novartis, Greensboro, NC) at $2.3 \mathrm{~kg}$ a.i./ha, glyphosate (Roundup 4L; Monsanto, St. Louis, MO) at $0.3 \mathrm{~kg}$ a.i./ha (sugarcane ripening application rate), pendimethalin (Prowl 3.3 EC; American Cyanamid, Wayne, $\mathrm{NJ}$ ) at $2.8 \mathrm{~kg}$ a.i./ha, metribuzin (Sencor $75 \mathrm{DF}$; DuPont, Wilmington, DE) at $2.0 \mathrm{~kg}$ a.i./ha, and terbacil (Sinbar $80 \mathrm{WP}$; DuPont) at $1.5 \mathrm{~kg}$ a.i./ha. Asulam (Asulox $3.34 \mathrm{AS}$; Rhone Poulenc, Research Triangle Park, NC) was applied at a rate of $3.8 \mathrm{~kg}$ a.i./ha in the second and third experiments. Control treatments with no herbicide application were included for comparison with herbicide treatments. Herbicides were applied to plants with a $\mathrm{CO}_{2}$-pressurized sprayer at a spray volume of 190 liters per hectare and a pressure of $207 \mathrm{kPa}$. Plants were watered daily to maintain soil moisture level near field capacity and observed for phytotoxicity symptoms during the experimental period.

Comparisons within each FS were made to study the effects of herbicides on Pythium root rot severity and plant growth in the presence of the natural sugarcane soil microbial community in two different soil types. Individual herbicide treatments were compared with the no-herbicide-treated FS control. Comparisons within SFS were made to study the effects of herbicides on plant growth in the absence of the soil microbial community. Individual herbicide treatments were compared with the no-herbicide-treated SFS control. Comparisons within SFS $+\mathrm{Pa}$ were made to study the effects of herbicides on Pythium root rot and plant growth when $P$. arrhenomanes was present without the sugarcane soil microbial community. Individual herbicide treatments were compared with the no-herbicide-treated SFS+Pa control.

The effects of herbicides on root rot severity and shoot and root growth were evaluated 8 to 10 weeks after treatment. Each plant was removed from the pot, and the root system was gently washed free of soil. Measurements included total shoot number per plant, root system fresh weight, and total shoot dry weight. In addition, the root system of each plant was evaluated visually and rated subjectively on the amount of reduction in lateral roots and the degree of discoloration caused by root rot compared with the root system of plants grown in SFS. Ratings were made on a scale of 1 to 4 , in which $1=$ normal appearance, no discoloration or reduction of the lateral root system; $1.5=$ very mild disease, up to $10 \%$ root system discoloration or reduction in lateral roots; $2=$ mild disease, $>10$ to $25 \%$ root system discoloration or reduction in lateral roots; $2.5=$ moderate disease, $>25$ to $50 \%$ root system discoloration or reduction in lateral roots; $3=$ severe disease, $>50$ to $75 \%$ root system discoloration or reduction in lateral roots; 3.5 $=$ very severe disease, $>75$ to $90 \%$ root system discoloration or reduction in lateral roots; and $4=$ completely diseased, $>90 \%$ of the root system discolored or reduction in lateral roots caused by root rot. Each root disease rating value was converted to its percentage midpoint before data analysis.

The extent of root colonization by Pythium spp. was determined for a total of $150 \mathrm{~cm}$ of root length per treatment. Six $5-\mathrm{cm}$ lengths of root were collected from each of five replicate plants per treatment. Three root pieces per 9-cm-diameter petri dish were immersed in PVPS, a modified Pythium-selective medium (33). To prepare PVPS, $10 \mathrm{~g}$ each of cornmeal agar and agar were autoclaved in 1 liter of distilled water. After cooling to 40 to $45^{\circ} \mathrm{C}$, the medium was amended with $300 \mathrm{mg}$ of vancomycin dissolved in $10 \mathrm{ml}$ of sterile water, $15 \mathrm{mg}$ of pentachloronitrobenzene dissolved in $2 \mathrm{ml}$ of $95 \%$ ethyl alcohol, $0.4 \mathrm{ml}$ of pimaricin (10 mg a.i./liter), and $300 \mathrm{mg}$ of spectinomycin dissolved in $10 \mathrm{ml}$ of sterile water. The medium was then poured over the roots until they were covered. Plates were incubated at room temper- ature $\left(24\right.$ to $\left.26^{\circ} \mathrm{C}\right)$. After 24 to $36 \mathrm{~h}$, the number of centimeters of root from which Pythium mycelium was growing into the medium was determined. The percent root length colonized by Pythium spp. was then calculated for each plant as the number of centimeters of root colonized divided by the total plated $(30 \mathrm{~cm})$ multiplied by 100 .

A subset of six Pythium isolates from each plate (12 isolates for each of the five replicate plants) was transferred to individual petri dishes containing V8 medium (200 $\mathrm{ml}$ of V8 vegetable juice cocktail per liter and $15 \mathrm{~g}$ of agar, $\mathrm{pH} 4.8$, amended after autoclaving with $300 \mu \mathrm{g}$ of penicillin). After 24 to $48 \mathrm{~h}$, six to eight agar plugs, $3 \mathrm{~mm}$ in diameter, containing actively growing mycelium of each isolate were transferred into a 5.5 -cm-diameter petri dish and flooded with $5 \mathrm{ml}$ of filter-sterilized soil extract. After 2 to 3 days at room temperature, identification of $P$. arrhenomanes isolates was accomplished by microscopic examination of reproductive structures (42). The proportion of isolates from each plant was used to convert the percent root length colonized by Pythium spp. to length colonized by $P$. arrhenomanes. A mean for the percent root length colonized by $P$. arrhenomanes was then determined for each treatment.

A completely randomized design with five replications was used in all three experiments. Percent root length colonized by $P$. arrhenomanes and root disease rating data (converted to the midpoints for the rating percentage intervals) were transformed to arcsine before analysis. Data for treatments within each soil treatment (silt loam FS, clay loam FS, or silt loam SFS-Pa with their corresponding SFS) were each subjected to analysis of variance for individual and combined experiments by using the general linear model procedures of the Statistical Analysis System, Version 6.2 (SAS Institute, Cary, NC). Differences among treatment means were determined with Fisher's protected least significant difference test at the $5 \%$ level of probability. Results are presented from the combined analysis of the three experiments for clay loam and silt loam field soil and silt loam soil infested with $P$. arrhenomanes and their corresponding SFS. Individual experiment results for all herbicides have been reported (11). Asulam was included in only two experiments, so the results are described in the text.

Treatment-by-soil type interactions were detected, so the results for the clay loam and silt loam field soils are presented separately. An additional analysis was performed to study the effects of herbicides in different soil types accounting for the treatment-by-soil type interaction. The mean of the control for each plant growth parameter and root rot severity rating in each soil type was divided by the corresponding herbicide values for individual replicates in all three experiments. The calculated values were then compared for each herbicide in clay loam and silt loam soil or silt loam and SFS+Pa with $t$ tests. A significant treatment-by-experiment interaction also was detected. Variability between experiments for the different herbicides is described in the text.

Evaluation of herbicide effects on in vitro mycelial growth of $\boldsymbol{P}$. arrhenomanes. Cornmeal agar (Difco, Detroit, MI) was amended with the commercial formulations of asulam, atrazine, glyphosate, pendimethalin, metribuzin, and terbacil at zero, one, two, three, four, and five times the recommended application rates (used in greenhouse studies). The concentrations of herbicide active ingredient in $15 \mathrm{ml}$ of agar in a 9-cm-diameter petri dish for the zero- to five-times rates were, respectively, 0, 87, 173, 260, 346, and $433 \mathrm{ppm}$ for atrazine; 0, 147, 293, 440, 586, and $733 \mathrm{ppm}$ for asulam; 0, 7, 13, 20, 26, and $33 \mathrm{ppm}$ for glyphosate; 0, 107, 213, 320,426 , and $533 \mathrm{ppm}$ for pendimethalin; 0, 80, 160, 240, 320, and $400 \mathrm{ppm}$ for metribuzin; and 0,60,120,180, 240, and $300 \mathrm{ppm}$ for terbacil.

Agar plugs, $3 \mathrm{~mm}$ in diameter, were removed from the margins of actively growing colonies of $P$. arrhenomanes, placed in the centers of herbicide-amended plates, and incubated at room temperature $\left(24\right.$ to $\left.26^{\circ} \mathrm{C}\right)$. Radial growth of mycelium from the center was recorded at 24 and $48 \mathrm{~h}$. A mycelial growth rate per $24 \mathrm{~h}$ was then calculated. Each treatment was replicated six times and arranged in a completely randomized design. The experiment was repeated once. 
Data for both experiments were combined and subjected to linear regression analysis (SAS, Version 6.2) to determine the effect of herbicide concentration on mycelial growth. In addition, mycelial growth rate data for the different herbicides were compared for each label rate multiple by Fisher's protected least significant difference test.

\section{RESULTS}

Asulam, atrazine, and metribuzin did not induce visible injury or phytotoxicity symptoms in roots or shoots of sugarcane plants. Pendimethalin caused varying degrees of stunting and clubbing of roots. This response was consistent for both soil types whether or not Pythium inoculum was added. Terbacil and glyphosate caused varying degrees of visible phytotoxicity symptoms in shoots in all studies. The symptoms were droopy, flaccid, and yellow or necrotic leaves and marked growth reduction throughout the experimental period.

An analysis of all the results combined indicated that root fresh weight, shoot dry weight, and shoot number were lower and root rot variables were higher for plants grown in each FS compared with plants grown in SFS. Plants grown in SFS+Pa exhibited additional reductions in plant growth and increased root rot severity compared with plants grown in FS.

Herbicide effects on root fresh weight. Glyphosate, pendimethalin, and terbacil reduced root fresh weight of plants grown in both field soils and the corresponding SFS compared with plants in the respective no-herbicide treatments (Table 1). Glyphosate and terbacil also reduced root weight in both SFS and SFS+Pa (Table 1). Root fresh weight was reduced by pendimethalin treatment in $\mathrm{SFS}+\mathrm{Pa}$ but not in SFS. The detrimental effect of glyphosate and terbacil was not evident in SFS in one experiment, while there were reductions in root weight for glyphosate-treated plants in clay loam soil and SFS+Pa and for terbacil-treated plants in SFS+Pa.

TABLE 1. Effects of herbicides on root fresh weight of sugarcane grown in clay loam and silt field soils (FS), steam-treated clay loam and silt loam soil (SFS), and steam-treated silt loam soil infested with Pythium arrhenomanes (SFS+Pa)

\begin{tabular}{|c|c|c|c|c|c|}
\hline \multirow[b]{3}{*}{ Treatment } & \multicolumn{5}{|c|}{ Root fresh weight $(\mathrm{g})^{\mathrm{z}}$} \\
\hline & \multicolumn{2}{|c|}{ Clay loam } & \multicolumn{3}{|c|}{ Silt loam } \\
\hline & FS & SFS & FS & SFS & $\mathrm{SFS}+\mathrm{Pa}$ \\
\hline No herbicide & $16.8 \mathrm{a}$ & $24.8 \mathrm{~b}$ & $18.0 \mathrm{ab}$ & $30.5 \mathrm{a}$ & $13.7 \mathrm{a}$ \\
\hline Atrazine & $18.5 \mathrm{a}$ & $32.1 \mathrm{a}$ & $20.3 \mathrm{a}$ & $31.7 \mathrm{a}$ & $14.3 \mathrm{a}$ \\
\hline Glyphosate & $6.3 \mathrm{~d}$ & $12.2 \mathrm{e}$ & $8.7 \mathrm{e}$ & $15.4 \mathrm{e}$ & $6.1 \mathrm{c}$ \\
\hline Metribuzin & $17.1 \mathrm{a}$ & $25.5 \mathrm{~b}$ & $17.3 \mathrm{~b}$ & $31.5 \mathrm{a}$ & $14.3 \mathrm{a}$ \\
\hline Pendimethalin & $13.5 \mathrm{~b}$ & $21.8 \mathrm{c}$ & $14.7 \mathrm{c}$ & $23.2 \mathrm{~b}$ & $9.4 \mathrm{~b}$ \\
\hline Terbacil & $8.9 \mathrm{c}$ & $8.9 \mathrm{f}$ & $11.5 \mathrm{~d}$ & $13.6 \mathrm{c}$ & $7.3 \mathrm{c}$ \\
\hline
\end{tabular}

${ }^{\mathrm{z}}$ Each value within an individual soil type represents a mean from three experiments. Means followed by the same letter within a soil type and within FS or SFS are not different $(P>0.05)$ from each other as assessed by Fisher's protected least significant difference test.

TABLE 2. Effects of herbicides on shoot dry weight of sugarcane grown in clay loam and silt loam field soils (FS), steam-treated clay loam and silt loam soil (SFS), and steam-treated silt loam soil infested with Pythium arrhenomanes $(\mathrm{SFS}+\mathrm{Pa})$

\begin{tabular}{|c|c|c|c|c|c|}
\hline \multirow[b]{3}{*}{ Treatment } & \multicolumn{5}{|c|}{ Shoot dry weight $(\mathrm{g})^{\mathrm{z}}$} \\
\hline & \multicolumn{2}{|c|}{ Clay loam } & \multicolumn{3}{|c|}{ Silt loam } \\
\hline & FS & SFS & FS & SFS & $\mathrm{SFS}+\mathrm{Pa}$ \\
\hline No herbicide & $9.3 \mathrm{a}$ & $12.0 \mathrm{~b}$ & $8.0 \mathrm{~b}$ & $13.0 \mathrm{a}$ & $6.8 \mathrm{a}$ \\
\hline Atrazine & $9.6 \mathrm{a}$ & $14.1 \mathrm{a}$ & $9.6 \mathrm{a}$ & $13.7 \mathrm{a}$ & $6.9 \mathrm{a}$ \\
\hline Glyphosate & $4.3 \mathrm{c}$ & $6.9 \mathrm{~d}$ & $4.9 \mathrm{~d}$ & $8.4 \mathrm{~d}$ & $3.7 \mathrm{~b}$ \\
\hline Metribuzin & $8.9 \mathrm{a}$ & $12.2 \mathrm{~b}$ & $8.5 \mathrm{~b}$ & $12.9 \mathrm{ab}$ & $6.4 \mathrm{a}$ \\
\hline Pendimethalin & $8.8 \mathrm{a}$ & $11.2 \mathrm{bc}$ & $8.4 \mathrm{~b}$ & $8.5 \mathrm{~b}$ & $6.4 \mathrm{a}$ \\
\hline Terbacil & $2.1 \mathrm{c}$ & $5.7 \mathrm{e}$ & $5.4 \mathrm{~d}$ & $6.8 \mathrm{~d}$ & $5.0 \mathrm{~b}$ \\
\hline
\end{tabular}

${ }^{\mathrm{z}}$ Each value within an individual soil type represents a mean from three experiments. Means followed by the same letter within a soil type and within FS or SFS are not different $(P>0.05)$ from each other as assessed by Fisher's protected least significant difference test.
Asulam, atrazine, and metribuzin generally did not reduce root weight of treated plants (Table 1). In the individual experiment analyses, asulam increased root weight in nonsterile and steam-treated clay loam soil and nonsterile silt loam soil in one experiment and had no effect on root weight in the other experiment. Atrazine treatment increased root fresh weight of plants grown in clay loam SFS. In one experiment, root weight of treated plants was reduced in SFS+Pa but not in SFS. Metribuzin did not affect root fresh weight of plants grown in clay or silt loam soil or the corresponding SFS. Metribuzin-treated plants had lower root weight in SFS+Pa in one experiment, without any reductions in SFS, but root weight was higher for treated plants in SFS-Pa in another experiment.

Herbicide effects on shoot dry weight. Glyphosate and terbacil reduced shoot dry weight in all nonsterile and steam-treated soils (Table 2). Reductions in shoot weight for glyphosate-treated plants in nonsterile clay loam soil and glyphosate- and terbacil-treated plants in SFS+Pa in the absence of growth reductions for plants in the corresponding SFS were detected in at least one experiment.

Pendimethalin had no effect on shoot dry weight in any soil for the combined analysis (Table 2). However, there were variable effects among individual experiments. Pendimethalin reduced shoot dry weight in steam-treated clay loam soil in two experiments while increasing shoot weight in the other experiment.

Asulam, atrazine, and metribuzin did not reduce shoot dry weight in nonsterile or steam-treated soil of any type (Table 2). Atrazine increased shoot weight in silt loam soil. In one experiment, a decrease in shoot weight in SFS+Pa, without any detrimental effect in SFS, was detected in atrazine- and metribuzin-treated plants.

Herbicide effects on shoot production. Terbacil reduced shoot number per plant in FS and SFS of clay loam soil but only in SFS

TABLE 3. Effects of herbicides on production of shoots in sugarcane grown in clay loam and silt loam field soils (FS), steam-treated clay loam and silt loam soil (SFS), and steam-treated silt loam soil infested with Pythium arrhenomanes $(\mathrm{SFS}+\mathrm{Pa})$

\begin{tabular}{|c|c|c|c|c|c|}
\hline \multirow[b]{3}{*}{ Treatment } & \multicolumn{5}{|c|}{ Shoot number per plant ${ }^{\mathrm{Z}}$} \\
\hline & \multicolumn{2}{|c|}{ Clay loam } & \multicolumn{3}{|c|}{ Silt loam } \\
\hline & FS & SFS & FS & SFS & $\mathrm{SPS}+\mathrm{Pa}$ \\
\hline No herbicide & $3.5 \mathrm{~b}$ & $5.1 \mathrm{~b}$ & $2.9 \mathrm{c}$ & $6.1 \mathrm{a}$ & $3.3 \mathrm{a}$ \\
\hline Atrazine & $4.0 \mathrm{ab}$ & $6.3 \mathrm{a}$ & $4.7 \mathrm{a}$ & $5.9 \mathrm{a}$ & $2.8 \mathrm{a}$ \\
\hline Glyphosate & $4.7 \mathrm{a}$ & $6.0 \mathrm{a}$ & $3.1 \mathrm{bc}$ & $5.8 \mathrm{ab}$ & $3.3 \mathrm{a}$ \\
\hline Metribuzin & $3.7 \mathrm{~b}$ & $5.5 \mathrm{ab}$ & $3.6 \mathrm{~b}$ & $6.1 \mathrm{ab}$ & $2.8 \mathrm{a}$ \\
\hline Pendimethalin & $3.7 \mathrm{~b}$ & $4.1 \mathrm{c}$ & $3.1 \mathrm{bc}$ & $5.9 \mathrm{a}$ & $1.9 \mathrm{~b}$ \\
\hline Terbacil & $2.3 \mathrm{c}$ & $3.2 \mathrm{~d}$ & $2.7 \mathrm{c}$ & $5.2 \mathrm{~b}$ & $2.9 \mathrm{a}$ \\
\hline
\end{tabular}

${ }^{\mathrm{z}}$ Each value within a individual soil type represents a mean from three experiments. Means followed by the same letter within a soil type and within FS or SFS are not different $(P>0.05)$ from each other as assessed by Fisher's protected least significant difference test.

TABLE 4. Effects of herbicides on lateral root system reduction of sugarcane grown in clay loam and silt loam field soils (FS), steam-treated clay loam and silt loam soil (SFS), and steam-treated silt loam soil infested with Pythium arrhenomanes $(\mathrm{SFS}+\mathrm{Pa})$

\begin{tabular}{|c|c|c|c|c|c|}
\hline \multirow[b]{3}{*}{ Treatment } & \multicolumn{5}{|c|}{ Lateral root system reduction $(\%)^{\mathrm{z}}$} \\
\hline & \multicolumn{2}{|c|}{ Clay loam } & \multicolumn{3}{|c|}{ Silt loam } \\
\hline & FS & SFS & FS & SFS & $\mathrm{SFS}+\mathrm{Pa}$ \\
\hline No herbicide & $35 \mathrm{c}$ & $0 \mathrm{c}$ & $32 \mathrm{~cd}$ & $0 \mathrm{~d}$ & $48 \mathrm{~b}$ \\
\hline Atrazine & $30 \mathrm{~d}$ & $0 \mathrm{c}$ & $25 \mathrm{~d}$ & $0 \mathrm{~d}$ & $49 \mathrm{~b}$ \\
\hline Glyphosate & $55 \mathrm{a}$ & $14 \mathrm{~b}$ & $56 a$ & $26 \mathrm{a}$ & $65 \mathrm{a}$ \\
\hline Metribuzin & $31 \mathrm{~cd}$ & $0 \mathrm{c}$ & $31 \mathrm{~cd}$ & $0 \mathrm{~d}$ & $52 \mathrm{~b}$ \\
\hline Pendimethalin & $45 \mathrm{~b}$ & $14 \mathrm{~b}$ & $38 \mathrm{c}$ & $7 \mathrm{c}$ & $62 \mathrm{a}$ \\
\hline Terbacil & $53 a$ & $18 \mathrm{a}$ & $45 \mathrm{~b}$ & $13 \mathrm{~b}$ & $53 \mathrm{~b}$ \\
\hline
\end{tabular}

${ }^{\mathrm{z}}$ Lateral root system reduction was determined by comparison with the root systems of plants in the appropriate steam-treated soil treatment. Values followed by the same letter within an individual soil type and within FS or SFS are not different $(P>0.05)$ from each other as assessed by Fisher's protected least significant difference test. 
of silt loam soil (Table 3). Shoot number was not reduced in SFS+Pa (Table 3).

Glyphosate had variable effects on shoot number in different soil types. Shoot number was increased for treated plants in clay loam FS and SFS but unaffected in silt loam FS, SFS+Pa, and their corresponding SFS (Table 3). Variable effects of glyphosate treatment also were evident in the individual experiments. Shoot number was reduced by glyphosate treatment in FS, but not in SFS, for both clay loam and silt loam soils in the second experiment and in SFS+Pa, but not SFS, in the third experiment. Shoot number was higher or unchanged for glyphosate-treated plants in the other experiments.

Pendimethalin decreased shoot number in steam-treated clay loam soil and SFS+Pa but had no effect in silt loam soil (Table 3). In contrast, atrazine, asulam, and metribuzin had no effect on shoot number in the field soils, SFS+Pa, or the corresponding SFS, although atrazine and metribuzin increased shoot number in silt loam soil (Table 3). Each herbicide reduced shoot number in $\mathrm{SFS}+\mathrm{Pa}$, but not in SFS, in one experiment.

Herbicide effects on lateral roots. Glyphosate and terbacil reduced lateral roots in both clay loam and silt loam soils (Table 4). Glyphosate also reduced the amount of lateral roots in SFS+Pa (Table 4). Lateral root development was adversely affected by glyphosate and terbacil treatment in SFS of all types. Glyphosate reduced the lateral root system in silt loam soil and SFS+Pa, but not the respective SFS, in one experiment.

The effects of pendimethalin were variable. The lateral root system was reduced in clay loam soil, $\mathrm{SFS}+\mathrm{Pa}$, and corresponding SFS but not in silt loam soil (Table 4). In clay loam soil, lateral root development was less for treated plants in the first experiment, greater in the second experiment, and the same as that of nontreated plants in the third experiment.

Asulam, atrazine, and metribuzin generally had no adverse effect on the lateral root system in Pythium-infested soils or SFS (Table 4), with the exception that atrazine reduced lateral root rot in nonsterile clay loam soil. Atrazine and metribuzin increased lateral root rot in SFS+Pa without affecting lateral root development in SFS in one experiment.

Herbicide effects on root system discoloration. Glyphosate and terbacil increased root system discoloration in both soil types and SFS $+\mathrm{Pa}$ (Table 5). Pendimethalin increased root discoloration in clay loam soil and SFS+Pa, and metribuzin increased discoloration in SFS+Pa (Table 5). Other herbicides had no effect on root discoloration.

Herbicide effects on root colonization by $P$. arrhenomanes. Herbicide treatments generally did not affect the degree of root colonization by $P$. arrhenomanes detected in clay loam or silt loam soils (Table 6), with the exception of pendimethalin, which reduced root colonization in SFS+Pa (Table 6).

TABLE 5. Effects of herbicides on root system discoloration caused by root rot of sugarcane grown in clay loam and silt loam field soils (FS), steamtreated clay loam and silt loam soil (SFS), and steam-treated silt loam soil infested with Pythium arrhenomanes (SFS+Pa)

\begin{tabular}{lcccccc}
\hline & \multicolumn{5}{c}{ Root system discoloration $(\%)^{\mathrm{z}}$} \\
\cline { 2 - 3 } \cline { 5 - 7 } Treatment & \multicolumn{2}{c}{ Clay loam } & & \multicolumn{3}{c}{ Silt loam } \\
\cline { 2 - 3 } \cline { 5 - 7 } No herbicide & $28 \mathrm{c}$ & 0 & & $29 \mathrm{c}$ & 0 & $46 \mathrm{c}$ \\
Atrazine & $22 \mathrm{c}$ & 0 & & $27 \mathrm{c}$ & 0 & $49 \mathrm{c}$ \\
Glyphosate & $65 \mathrm{a}$ & 0 & & $63 \mathrm{a}$ & 0 & $70 \mathrm{a}$ \\
Metribuzin & $30 \mathrm{c}$ & 0 & & $26 \mathrm{~d}$ & 0 & $60 \mathrm{~b}$ \\
Pendimethalin & $45 \mathrm{~b}$ & 0 & & $37 \mathrm{c}$ & 0 & $58 \mathrm{~b}$ \\
Terbacil & $61 \mathrm{a}$ & 0 & & $53 \mathrm{~b}$ & 0 & $68 \mathrm{a}$ \\
\hline
\end{tabular}

${ }^{\mathrm{z}}$ Each value within an individual soil type represents a mean from three experiments. Means followed by the same letter within a soil type and within FS or SFS are not different $(P>0.05)$ from each other as assessed by Fisher's protected least significant difference test.
The extent of root colonization by $P$. arrhenomanes detected in the field soils ranged from 14 to $24 \%$ (Table 6), although the percentage of root length colonized by all Pythium spp. ranged from 68 to $90 \%$ (data not shown). In P. arrhenomanes-infested SFS, percent root colonization was higher and ranged from 76 to $90 \%$.

Comparison of herbicide effects in different soil types. A comparison of the effects of individual herbicides in different soil types (analysis not shown) determined which herbicides accounted for the herbicide-by-soil type interaction detected in the combined analysis. The effects of phytotoxic and nonphytotoxic herbicides were variable in clay loam and silt loam sugarcane field soils. Root and shoot weight reductions caused by glyphosate and shoot and lateral root reductions caused by terbacil were greater in clay loam than in silt loam soil. Increases in shoot weight and number resulting from application of the nonphytotoxic herbicides, asulam, atrazine, and metribuzin, were evident only in silt loam soil. A comparison of results in silt loam soil and SFS+Pa indicated that differences detected for plant growth parameters and disease ratings between herbicide-treated and control plants were always greater in SFS+Pa. No increases in growth resulted from herbicide treatment of plants in SFS+Pa.

Herbicide effects on mycelial growth of $P$. arrhenomanes. The mycelial growth rate of $P$. arrhenomanes in agar culture decreased with increasing concentrations of asulam, atrazine, pendimethalin, and metribuzin $\left(R^{2}=0.53,0.69,0.86\right.$, and 0.39 , respectively), whereas glyphosate and terbacil had no effect (Fig. 1). The effects of asulam and metribuzin on mycelial growth were minor. The growth of $P$. arrhenomanes was not reduced at all at a concentration equivalent to the label rate for each of these herbicides compared with growth rates in the absence of herbicide, and reductions of only 6 and $7 \%$ occurred at herbicide concentrations five times the recommended rate for asulam and metribuzin, respectively. Mycelial growth was reduced by asulam and metribuzin compared with glyphosate and terbacil at four and five times the recommended rates. Atrazine, at concentrations equivalent to the label rate and five times the label rate, decreased mycelial growth 12 and $25 \%$, respectively. The mycelial growth rate at each herbicide concentration was less for atrazine than for the other herbicides, except pendimethalin, which had an inhibitory effect greater than that of all the other herbicides at each rate multiple. Mycelial growth was reduced $49 \%$ at a herbicide concentration equivalent to the label rate, and growth was almost completely inhibited when the herbicide concentration was increased fivefold.

\section{DISCUSSION}

Six herbicides commonly applied during sugarcane cultivation had variable effects on plant growth, root rot, and $P$. arrhenomanes. Four inhibited in vitro mycelial growth of $P$. arrhenomanes to varying

TABLE 6. Effects of herbicides on root colonization by Pythium arrhenomanes of sugarcane grown in clay loam and silt loam field soils (FS), steamtreated clay loam and silt loam soil (SFS), and steam-treated silt loam soil infested with $P$. arrhenomanes (SFS+Pa)

\begin{tabular}{lcccccc}
\hline & \multicolumn{3}{c}{ Root colonization by P. arrhenomanes $(\%)^{\mathrm{z}}$} \\
\cline { 2 - 3 } \cline { 5 - 7 } Treatment & \multicolumn{2}{c}{ Clay loam } & & \multicolumn{3}{c}{ Silt loam } \\
\cline { 2 - 3 } \cline { 5 - 7 } No herbicide & FS & SFS & & FS & SFS & SFS+Pa \\
Atrazine & 24 & 0 & & 18 & 0 & $84 \mathrm{ab}$ \\
Glyphosate & 20 & 0 & & 18 & 0 & $80 \mathrm{bc}$ \\
Metribuzin & 18 & 0 & & 15 & 0 & $84 \mathrm{ab}$ \\
Pendimethalin & 20 & 0 & & 16 & 0 & $77 \mathrm{bc}$ \\
Terbacil & 20 & 0 & & 17 & 0 & $76 \mathrm{c}$ \\
\hline
\end{tabular}

${ }^{\mathrm{z}}$ Percent root colonization was determined from six 5-cm lengths of root from each of five replicate plants per treatment. Each value within an individual soil type represents a mean from three experiments. Means followed by the same letter within a soil type and within FS or SFS are not different $(P>0.05)$ from each other as assessed by Fisher's protected least significant difference test. 
degrees. However, inhibition was not associated with reductions in root rot symptom severity. Herbicide phytotoxicity to sugarcane was associated with effects on plant growth and disease severity.

The three herbicides, asulam, atrazine, and metribuzin, that were not phytotoxic in this study did not adversely affect root and shoot growth nor increase root rot severity when applied at recommended rates to plants in nonsterile clay loam soil. However, atrazine and metribuzin had variable effects on disease severity and plant growth in silt loam soil, steam-treated soils, and steamtreated soil infested with $P$. arrhenomanes.

Field studies have shown that asulam can be phytotoxic to some sugarcane cultivars (9). Phytotoxicity symptoms were not observed in asulam-treated plants in this study. However, CP 70-321, the cultivar used in this study, is more tolerant of asulam than the other cultivars currently grown in Louisiana.

Atrazine applications to plants growing in Pythium-infested field soils sometimes resulted in increased root and shoot growth. Atrazine inhibited mycelial growth of $P$. arrhenomanes in vitro when applied at the label rate. However, root colonization by $P$. arrhenomanes was unaffected by atrazine in field soils and steamtreated soil infested with the pathogen. In addition, root rot symptom severity was not reduced, and growth increases occurred in treated plants grown in steam-treated soils. A previous study showed that application of triazine herbicides, such as atrazine, had beneficial effects on growth resulting in increased root and shoot growth of pea and sweet corn (44). The mechanism of stimulation was shown to be an increase in the activity of nitrate reductase and transaminase, enzymes related to protein synthesis (36).

The other three herbicides, glyphosate, pendimethalin, and terbacil, were phytotoxic to sugarcane. Visible symptoms of phytotoxicity and growth reductions were observed for plants in steam-treated soils. Herbicide treatment resulted in increased disease severity and, in some cases, additional reductions in plant growth in both field soils and steam-treated soil infested with $P$. arrhenomanes.

The adverse effects of pendimethalin on sugarcane growth in the present study could be attributed to both direct injury and increased severity of Pythium root rot. The presence of short, stubby roots with no lateral roots, rather than normal primary roots with many lateral roots, could adversely affect plant growth, but pedimethalin treatment had erratic effects on plant growth parameters

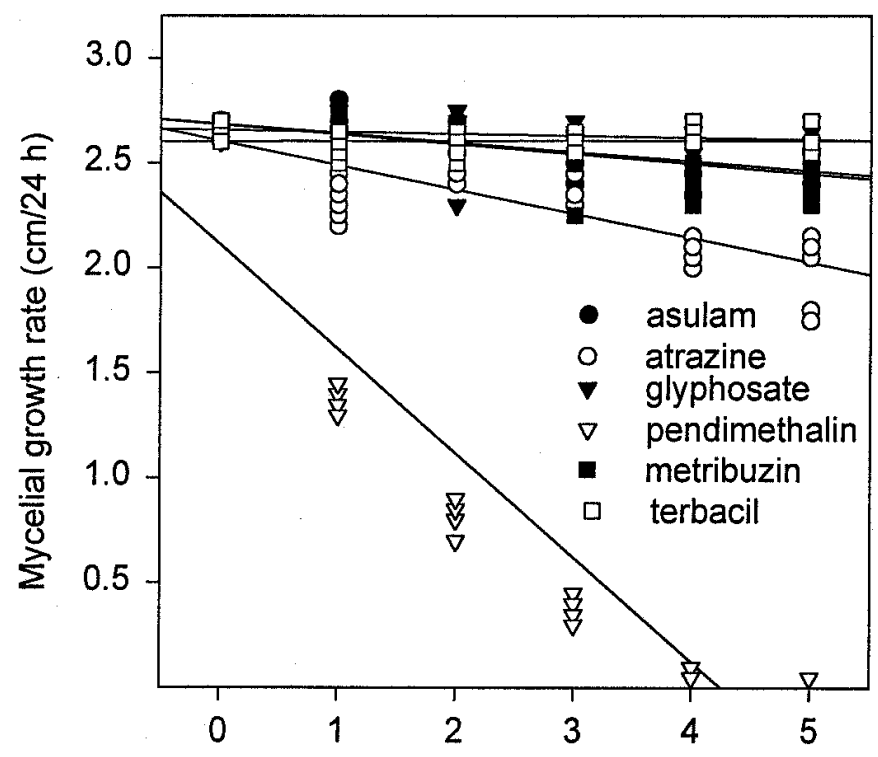

Multiple of label herbicide application rate

Fig. 1. Results of linear regression analysis to determine the effects of six herbicides on in vitro mycelial growth rate of Pythium arrhenomanes. Agar medium was amended with concentrations equivalent to zero, one, two, three, four, and five times the label application rate for each herbicide. in steam-treated soil. Decreases in plant growth were observed in Pythium-infested soils in association with increases in root rot symptom severity, and sometimes these effects occurred without any effect of herbicide treatment on plants in steam-treated soil. These results suggest that pendimethalin can decrease sugarcane growth by causing an increase in the severity of root rot.

The in vitro study results indicated a strong inhibitory effect of pendimethalin on mycelial growth of $P$. arrhenomanes. Dinitroaniline herbicides have been shown to have inhibitory effects on Aphanomyces $(18,41)$ Phytophthora (43), and Pythium (1) spp. Root colonization by $P$. arrhenomanes was reduced for herbicidetreated plants in only one experiment with steamed soil infested with $P$. arrhenomanes (11), but root rot symptom severity was increased rather than decreased. Pea root rot severity was reduced, but dinitroaniline herbicide effects on diseases of vegetables were variable with different Pythium spp. $(19,40,41)$. Pendimethalin reduced the incidence of crown rot of cherry when applied at a rate close to that used in this study (43). Growth of pendimethalin-treated sugarcane plants in nonsterile field soil and in steam-treated soil infested with $P$. arrhenomanes was either unaffected or reduced.

Glyphosate is applied as a herbicide during the fallow period or with spray equipment that avoids chemical contact with sugarcane. It also is commonly applied as a ripening agent to ratoon crops to increase sugar content (13). Glyphosate is absorbed through foliar tissues and readily translocated to underground plant tissues where interactions with soil and rhizosphere microorganisms can occur $(30,38,39)$. In this investigation, glyphosate applied at the rate recommended for use as a ripening agent reduced root and shoot growth in both field soil types and steam-treated soil infested with $P$. arrhenomanes. Phytotoxicity often caused plant growth reductions in steam-treated soils. In Pythium-infested soils, it was difficult to distinguish growth reductions caused by root rot from those caused by direct herbicide injury. Furthermore, it was impossible to determine whether the amount of direct injury to treated plants in steam-treated soil was the same as that to plants in nonsterile field soil. However, disease symptom severity was always greater in nonsterile field soils and $P$. arrhenomanes-infested steamed soil, and in some cases, the growth reductions observed for treated plants did not occur in steam-treated soil. This suggests that glyphosate can reduce sugarcane growth by increasing the severity of root rot. A previous report indicated that glyphosate application caused injury and death of Italian ryegrass, Lolium multiflorum, as a result of increased Pythium root rot (28). In addition, sublethal doses of glyphosate inhibited the expression of resistance in soybean to Phytophthora megasperma f. sp. glycinea (29), in bean to Colletotrichum lindemuthianum (25), and in tomato to Fusarium spp. (7).

The effects of terbacil were similar to those of glyphosate. Terbacil reduced root and shoot growth in nonsterile soils and steam-treated soil infested with $P$. arrhenomanes. However, phytotoxicity caused growth reductions in plants grown in steam-treated soils. The direct plant injury caused by terbacil in steamed soil again made it difficult to determine the relative amount of damage in Pythium-infested soils caused by direct injury and that caused by an interaction among the herbicide, sugarcane, and pathogen resulting in increased disease severity. As with glyphosate, plant growth reductions in nonsterile soil were associated with increased disease symptom severity, and in one experiment with $P$. arrhenomanes-infested soil, no growth reductions occurred in plants in steam-treated soil. These results suggest that terbacil is also capable of decreasing sugarcane growth by increasing root rot severity. Sugarcane injury resulting from terbacil treatment has been reported on crops grown in silt loam soil (32).

Pendimethalin and terbacil are applied during the fall and early spring, and plant stress and an increase in the occurrence and severity of Pythium root rot could result. Glyphosate, used as a ripening agent during late summer, can cause direct injury and stress, thereby predisposing plants to root rot. This could be a factor in the reduction in yield documented in one study in the first ratoon crop after treatment (35). 
Herbicide effects differed among the soil types included in the study. Herbicide injury and increases in disease severity occurred in treated plants in both clay loam and silt loam soils. However, the injurious herbicides, glyphosate, pendimethalin, and terbacil, had greater adverse effects on sugarcane growth and root rot severity in clay loam soil. In contrast, increases in plant growth resulting from application of asulam, atrazine, and metribuzin occurred only in silt loam soil.

Herbicides that increased root rot symptom severity and reduced plant growth did not affect the measured root colonization by $P$. arrhenomanes. Infection levels in steamed soil infested with the pathogen were already high without herbicides, but the lower infection levels detected in the two field soils were also unchanged after herbicide application. When isolations were made from segments of primary roots with lateral roots attached at the conclusion of an experiment, the types of tissues infected, time course, and duration of infections were unknown. Levels of root infection by $P$. arrhenomanes detected by isolation fluctuated widely in corn depending on soil moisture conditions (10). Thus, the sampling and isolation method employed may not have been adequate to determine the effects of herbicides on P. arrhenomanes ecology and sugarcane root rot epidemiology.

The indirect effects of herbicides on crop plants and soilborne diseases are often not considered. The potential exists for increased root rot severity in sugarcane treated with the herbicides currently in use. The results of the present study indicate the importance of observations on root health as an added component of herbicide evaluation trials. It would be relevant to make observations of root injury and root rot, particularly when plants exhibit foliar herbicide injury.

\section{ACKNOWLEDGMENTS}

Approved for publication by the director of the Louisiana Agricultural Experiment Station as manuscript 97-38-0289. We thank L. B. Grelen, S. Bodden, Z. Yin, and P. Clay for technical assistance.

\section{LITERATURE CITED}

1. Abdalla, M. H., and Manci, S. F. 1979. Interaction between a Pythium and the herbicide "Stomp." Trans. Br. Mycol. Soc. 72:213.

2. Altman, J. 1993. Pesticide-pathogen interactions in plant diseases. Pages 315-332 in: Pesticide Interactions in Crop Production. Beneficial and Deleterious Effects. J. Altman, ed. CRC Press, Boca Raton, FL.

3. Altman, J., and Campbell, C. L. 1977. Effect of herbicides on plant diseases. Annu. Rev. Phytopathol. 15:361-385.

4. Altman, J., and Rovira, A. D. 1989. Herbicide-pathogen interactions in soilborne root diseases. Can. J. Plant Pathol. 11:166-172.

5. Bollen, G. J. 1979. Side-effects of pesticides on microbial interactions. Pages 451-481 in: Soilborne Plant Pathogens. B. Schippers and W. Gams, eds. Academic Press, New York.

6. Bollen, G. J. 1993. Mechanisms involved in nontarget effects of pesticides on soilborne pathogens. Pages 281-301 in: Pesticide Interactions in Crop Production. Beneficial and Deleterious Effects. J. Altman, ed. CRC Press, Boca Raton, FL.

7. Brammal, R. A., and Higgins, V. J. 1988. The effects of glyphosate on resistance of tomato to Fusarium crown rot and root rot diseases and on the formation of host structural defence barriers. Can. J. Bot. 66:1547-1555.

8. Brown, S. L., and Curl, C. A. 1987. Rhizosphere effects of herbicidestressed sicklepod (Cassia obtusifolia) on chlamydospores of Fusarium oxysporum f. sp. vasinfectum. Plant Dis. 71:919-922.

9. Bruff, S. A., and Griffin, J. L. 1994. Johnsongrass (Sorghum halepense) control and sugarcane (Saccharum spp.) response to time of asulox application. (Abstr.) J. Am. Soc. Sugar Cane Technol. 14:78-79.

10. Deep, I. W., and Lipps, P. E. 1996. Recovery of Pythium arrhenomanes and its virulence to corn. Crop Prot. 15:85-92.

11. Dissanayake, N. 1995. Effects of organic waste amendments, herbicides, and weed hosts on Pythium root rot of sugarcane. Ph.D. diss. Louisiana State University, Baton Rouge.

12. Dissanayake, N., Hoy. J. W., and Griffin, J. L. 1995. Herbicide effects on Pythium arrhenomanes, Pythium root rot, and growth of sugarcane. (Abstr.) Phytopathology 85:1209.

13. Dusky, J. A., Kang, M. S., Glaz, B., and Miller, J. D. 1986. Response of eight sugarcane cultivars to glyphosine and glyphosate ripeners. J. Plant Growth Regul. 4:225-235.
14. Edgerton, C. W. 1939. Stubble deterioration. Proc. Int. Soc. Sugar Cane Technol. 6:334-341.

15. Edgerton, C. W., Tims, E. C., and Mills, P. J. 1929. Relation of species of Pythium to the root-rot disease of sugarcane. Phytopathology 19:549-564.

16. Edgerton, C. W., Tims, E. C., and Mills, P. J. 1934. Stubble deterioration of sugarcane. La. State Univ. Bull. 256.

17. Elad, Y., and Chet, I. 1987. Possible role of competition for nutrients in biocontrol of Pythium damping-off by bacteria. Phytopathology 77:190-195.

18. Grau, C. R. 1977. Effect of dinitramine and trifluralin on growth, reproduction, and infectivity of Aphanomyces euteiches. Phytopathology 67: 551-556.

19. Grau, C. R., and Reiling, T. P. 1977. Effects of trifluralin and dinitroamine on Aphanomyces root rot of pea. Phytopathology 67:273-276.

20. Grinstein, A., Lisker, N., Katan, J., and Eschel, Y. 1984. Herbicide-induced resistance to plant wilt diseases. Physiol. Plant Pathol. 24:347-356.

21. Hale, M. G., and Moore, L. D. 1979. Factors affecting root exudation. Adv. Agron. 31:93-126.

22. Hess, F. D. 1993. Herbicide effects on plant structure, physiology and biochemistry. Pages 13-36 in: Pesticide Interactions in Crop Production: Beneficial and Deleterious Effects. J. Altman, ed. CRC Press, Boca Raton, FL.

23. Hoy, J. W., and Schneider, R. W. 1988. Role of Pythium in sugarcane stubble decline: Pathogenicity and virulence of Pythium species. Phytopathology 78: 1688-1692.

24. Hoy, J. W., and Schneider, R. W. 1988. Role of Pythium in sugarcane stubble decline: Effects on plant growth in field soil. Phytopathology 78:1692-1696.

25. Johal, G. S., and Rahe, J. E. 1990. Role of phytoalexins in the suppression of resistance of Phaseolus vulgaris to Colletotrichum lindemuthianum by glyphosate. Can. J. Plant Pathol. 12:225-235.

26. Kao, C. W., and Ko, W. H. 1983. Nature and suppression of Pythium splendens in a pasture soil in South Kohala, Hawaii. Phytopathology 73:1284-1289.

27. Katan, J., and Eshel, Y. 1973. Interaction between herbicides and plant pathogens. Residue Rev. 45:145-177.

28. Kawate, M. K., and Appleby, A. P. 1987. Effect of soil pH on availability of glyphosate in soil to germinating ryegrass seedlings. J. Appl. Seed Prod. 5:45-49.

29. Keen, N. T., Holliday, M. J., and Yoshikawa, M. 1982. Effects of glyphosate on glyceollin production and the expression of resistance to Phytophthora megasperma f. sp. glycinea in soybean. Phytopathology 72: 1467-1470.

30. Levesque, C. A., and Rahe, J. E. 1992. Herbicide interactions with fungal root pathogens, with special reference to glyphosate. Annu. Rev. Phytopathol. 30:579-602.

31. Levesque, C. A., Rahe, J. E., and Eaves, D. M. 1987. Effects of glyphosate on Fusarium spp.: Its influence on root colonization of weeds, propagule density in soil, and crop emergence. Can. J. Microbiol. 33: 354-360.

32. Millhollon, R. W. 1993. Preemergence control of itchgrass (Rottboellia cochinchinensis) and johnsongrass (Sorghum halepense) in sugarcane (Saccharum spp. hybrids) with pendimethalin and prodiamine. Weed Sci. 41:621-626.

33. Mircetich, S. M., and Matheron, M. E. 1976. Phytophthora root and crown rot of cherry trees. Phytopathology 66:549-558.

34. Rands, R. D., and Dopp, E. 1938. Pythium root rot of sugarcane. U.S. Dep. Agric. Tech. Bull. 666.

35. Rice, E. R. 1983. The effect of Polaris and Polado on regrowth of two sugar cane varieties in Florida. (Abstr.) J. Am. Soc. Sugar Cane Technol. 2:86.

36. Ries, S. K., Chmiel, H., Dilly, D. R., and Filner, P. 1967. The increase in nitrate reductase activity and protein content of plants treated with simazine. Proc. Natl. Acad. Sci. USA 58:526-532.

37. Schuldt, P. N., and Wolfe, C. N. 1956. Fungitoxicity of substituted s-triazines. Contrib. Boyce Thompson Inst. 15:377-393.

38. Sprankle, P., Meggitt, W. F., and Penner, D. 1975. Rapid interaction of glyphosate in the soil. Weed Sci. 23:224-228.

39. Sprankle, P., Meggitt, W. F., and Penner, D. 1975. Absorption, action, and translocation of glyphosate. Weed Sci. 23:235-240.

40. Sumner, D. R. 1993. Interactions of pesticides with diseases of vegetables. Pages 303-313 in: Pesticide Interactions in Crop Production: Beneficial and Deleterious Effects. J. Altman, ed. CRC Press, Boca Raton, FL.

41. Teasdale, J. R., Harvey, R. G., and Hagedorn, D. J. 1979. Mechanism for the suppression of pea (Pisum sativum) root rot by dinitroaniline herbicides. Weed Sci. 27:195-201.

42. Van der Plaats-Niterink, A. J. 1981. Monograph of the Genus Pythium. Studies in Mycology, vol. 21. Centraalbureau voor Schimmelcultures, Baarn, Netherlands.

43. Wilcox, W. F. 1996. Influence of dinitroanaline herbicides on growth, sporulation, and infectivity of four Phytophthora spp. pathogenic to deciduous fruit trees. Phytopathology 86:906-913.

44. Wu, M. T., Singh, B., and Salunkhe, D. K. 1972. Influence of foliar application of s-triazine compounds on fresh weight, dry weight, chemical composition, and enzymatic activity of pea and sweet corn seedlings. J. Exp. Bot. 23:793-800. 